\title{
Erratum to: Anatomy and Aesthetics of the Labia Minora: The Ideal Vulva?
}

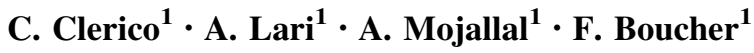

Published online: 7 April 2017

(C) Springer Science+Business Media New York and International Society of Aesthetic Plastic Surgery 2017

\section{Erratum to: Aesth Plast Surg \\ DOI 10.1007/s00266-017-0831-1}

The correct spelling of the second author's Family Name is "Lari".

The original article was corrected.

The online version of the original article can be found under doi:10. 1007/s00266-017-0831-1.

\section{Clerico \\ cyril.clerico@gmail.com}

1 Department of Plastic and Reconstructive Surgery, Croix-

Rousse Hospital, University of 103 Grande Rue de la Croix-

Rousse, 69004 Lyon, France 